\title{
磁気熱風の逆流について Reverse Flow of Magnetothermal wind
}

\author{
正 日向野 三雄 (秋県大) \\ 正 二村 宗男（秋県大） \\ 佐藤 行毅 (秋県大) \\ 正 赤松 正人（山形大）
}

Mitsuo HIGANO, Muneo FUTAMURA, and Koki SATO, Akita Prefectural University, Yuri-honjo, Akita Masato AKAMATSU, Yamagata University, Yonezawa, Yamagata

The magnetothermal wind is induced by the magnetic (Kelvin) force in two coaxial circular pipes with both thermal and magnetic gradients. When the one-turn electric coil as a source of the magnetic (Kelvin) force is placed at the upper end of the heated region of the inner pipe, the flow direction of the magnetothermal wind changes from the upward flow to downward flow with the increase of magnetic strength. The present study noticed the reverse flow of a magnetothermal wind under various Rayleigh numbers. Our numerical results showed that the critical magnetic strength caused the reverse flow was almost independent of Rayleigh number.

Key Words: Reverse flow, Natural convection, Vertical pipe, Magnetic field, Air.

\section{1. 緒言}

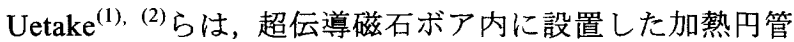
に磁場勾配を印加寸ると, 磁気(Kelvin)力により磁気熱風が 発生することを簡単な実験装置を使用して実証した。 Akamatsuら ${ }^{(3)}$ は, この新しい現象をモデル化し, 数值シミ ュレーションによって磁気熱風の流動特性を可視化した． そして, 勾配磁場の印加位置を変化させると磁気熱風が逆

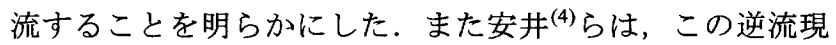
象が生じる磁場強度, 即ち臨界磁場強度 $\gamma_{\mathrm{cr}}$ をRayleigh数 10,000 の場合で求めた。

本研究の目的は, 安井らの研究を発展させ, 様々な Rayleigh 数と臨界磁場強度との関係を数值シミュレーショ ンによって明らかにすることである。

\section{2. 解析モデルおよび解析方法}

Fig.1(a)は超伝導磁石の写真であり，同(b)は本研究で用い る解析モデルである. 同モデルの外円管は, 超伝導磁石の ボア (直径 $0.1 \mathrm{~m}$ ) に相当する一定温度の冷却管で, その直径 と長さは, 同軸上にある内円管のそれらの 2.5 倍と 2 倍で ある。 また内円管は，その中央部を一定温度で加熱され， その他の部分は断熱とした。さらに一巻き円形電磁コイル は加熱部上端に設置され, その直径は内円管の 3 倍とした.

以下は無次元化された基礎方程式である.式(1)は連続の 式, 式(2),(3)は磁気力が付加された運動方程式, 式(4)は工 ネルギー方程式である.なお本解析モデルでは, 流れは層 流軸対称流れであると仮定した.

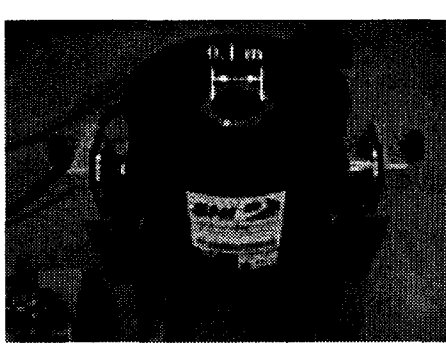

(a)

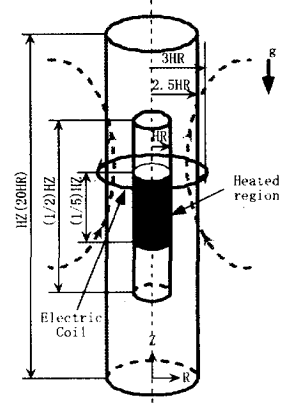

(b)
Fig.1 Super conducting magnet and schematic representation of the model system.

$$
\begin{aligned}
& \frac{1}{R} \frac{\partial}{\partial R}(R U)+\frac{\partial W}{\partial Z}=0 \\
& \frac{\partial U}{\partial \tau}+U \frac{\partial U}{\partial \boldsymbol{R}}+W \frac{\partial U}{\partial Z} \\
& =-\frac{\partial P}{\partial R}+\operatorname{Pr}\left[\frac{\partial}{\partial R}\left\{\frac{1}{R} \frac{\partial}{\partial R}(R U)\right\}+\frac{\partial^{2} U}{\partial Z^{2}}\right]-\gamma \operatorname{RaPr} T \frac{\partial B^{2}}{\partial R} \\
& \frac{\partial W}{\partial \tau}+U \frac{\partial W}{\partial R}+W \frac{\partial W}{\partial Z} \\
& =-\frac{\partial P}{\partial Z}+\operatorname{Pr}\left[\frac{1}{R} \frac{\partial}{\partial R}\left(R \frac{\partial W}{\partial R}\right)+\frac{\partial^{2} W}{\partial Z^{2}}\right]-\gamma \operatorname{RaPr} T \frac{\partial B^{2}}{\partial Z}+\operatorname{RaPr} T \\
& \frac{\partial T}{\partial \tau}+U \frac{\partial T}{\partial R}+W \frac{\partial T}{\partial Z}=\frac{1}{R} \frac{\partial}{\partial R}\left(R \frac{\partial T}{\partial R}\right)+\frac{\partial^{2} T}{\partial Z^{2}}
\end{aligned}
$$

支配パラメータは, 以下の 3 つの無次元数である.ここ で, $\gamma$ は無次元化した磁場の強さであり, 磁場強度と呼ぶ。

$$
\operatorname{Pr}=\frac{v}{\alpha}, \quad R a=\frac{g \beta\left(\theta_{\text {in }}-\theta_{\text {out }}\right) r^{3}}{\alpha \nu}, \quad \gamma=\frac{\chi b^{2}}{\xi g r} .
$$

$r$ は内冈管半径, $\chi$ は空気の質量磁化率, $b$ は磁束密度, $\xi$ は真空の透磁率， $g$ は重力加速度などである。

ボア内の非一様磁場は, 一巻き円形電磁コイルで発生す る磁場で置き換えた。この時の磁束密度の分布は, Biot-Savart の法則の式(5)を用いて計算した。

$$
\vec{B}=-\frac{1}{4 \pi} \oint \frac{\vec{R} \times d \vec{S}}{R^{3}}
$$

本数值シミュレーションでは, 空気のPrandtl数 $P r=0.71$ で固定し, Rayleigh数 $R a=5000,1 \times 10^{4}, 2 \times 10^{4}, 3 \times 10^{4}$ とし, 磁場強度 $\gamma=0 \sim 400$ まで変化させた。

初期条件は，速度，温度ともにゼロとした，速度の境界 条件としては, 外円管の上端, 下端で速度勾配がゼロとし た．また，外円管と内円管の側壁はすべり無しとした．温 度の境界条件としては, 外円管の上端, 下端で温度勾配が ゼロとし, 内, 外円管の温度境界条件は前述の通りである.

円形電磁コイルが加熱部上端に設置される場合, (1)印加 磁場が小さい時は上向きの磁気熱風が内円管上端から流出 し，(2)中程度では内円管内に静止し，(3)逆に磁場が大きい 時は下向きの流れとなって内円管下端から流出する。この 磁気熱風の逆流限界を示す臨界磁場強度 $\gamma_{\mathrm{cr}}$ を, 様々な Rayleigh数に対する $\gamma_{\mathrm{cr}}$ を数值シミュレーションで調べた。 


\section{3. 解析結果}

本研究では, 磁場強度 $\gamma=0 \sim 400$ で数值シミュレーショ ンを行ったが, 特に磁気熱風が静止, または逆流する磁場 強度の範囲 $250<y<350$ について考察を行なう.

Fig.2 は, 各磁場強度における磁気熱風の平均軸方向速度 $\bar{W}$ を示している.ここで平均軸方向速度 $\bar{W}$ は円管出口を通 過する空気流量を出口断面積で除した值である. 図から， 磁気熱風の逆流は，例えば $R a=3 \times 10^{4}$ の時（中実印）, $\gamma>285$ で生じていることが分かる.逆流域の $\gamma=338$ での 等温線図をFig.3(a)に，また内円管上下端での速度分布を Fig.3 (b)に示す. 逆流であるはずが, 円管上端の中央部に 上昇流が確認され，完全に逆流したとは言えない.

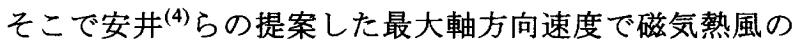
逆流を判断してみる. Fig.4(a)は, 各磁場強度における磁気 熱風の内円管出口での最大軸方向速度 $W_{\max }$ を示している. Fig.4 (b) は，磁気熱風が逆流する臨界磁場強度 $\gamma_{\mathrm{cr}}$ を決定す るための拡大表示である. Fig.4(b)から読み取った臨界磁場 強度 $\gamma_{\mathrm{cr}}$ の值をTable 1 に示し, それらをFig.5 に示す. 図か ら, Rayleigh数 $R a=5000 \sim 3 \times 10^{4}$ と大幅に変化しているの に対して, 臨界磁場強度 $\gamma_{\mathrm{cr}}$ はほぼ一定であり, 変化量は 約 $10 \%$ に過ぎないことが分かった。

\section{4. 結言}

円形電磁コイルの位置を加熱部上端で固定し，様々な Rayleigh数について磁場強度 $\gamma$ を変化させた時の磁気熱風 の流動特性を調べた結果, 磁気熱風が逆流する臨界磁場強 度 $\gamma_{\mathrm{cr}}$ はRayleigh数にほとんど依存しないことが分かった。

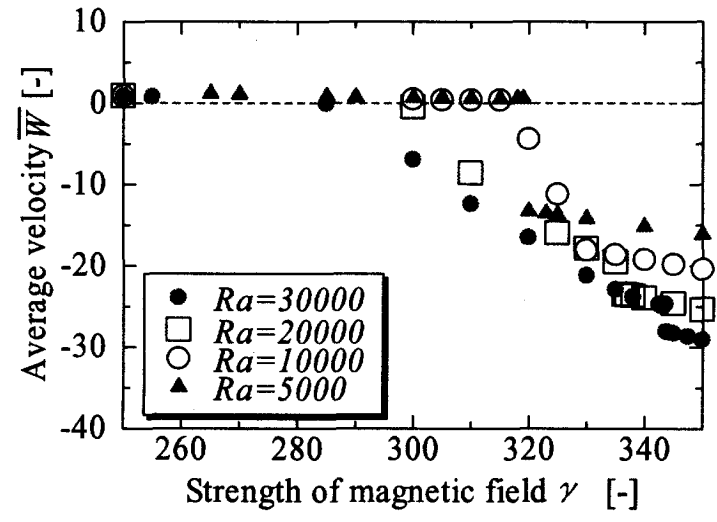

Fig.2 Average axial velocity versus magnetic strength $(250<\gamma<350)$.

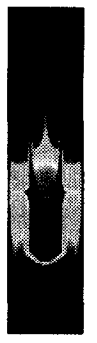

(a)

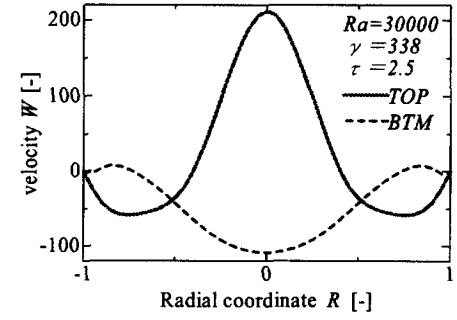

(b)
Fig.3 (a) Temperature distribution of magnetothermal wind and (b) velocity at the ends of the inner pipe for $y=338, \operatorname{Pr}=0.71$ and $R a=3 \times 10^{4}$.

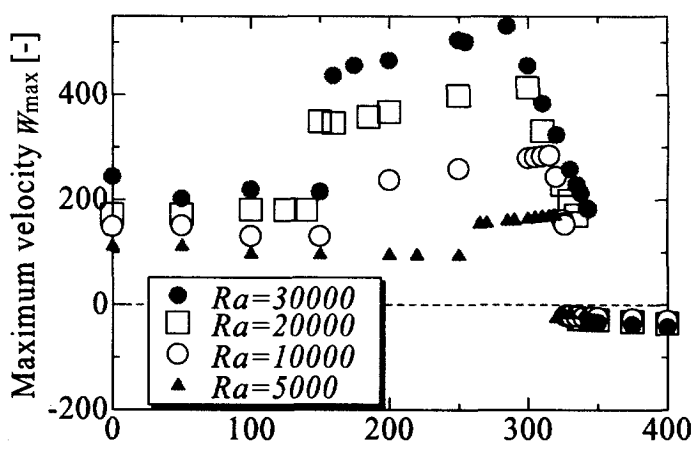

Strength of magnetic field $\gamma[-]$

Fig.4 (a) Maximum axial velocity versus magnetic strength $(0<\gamma<400)$.

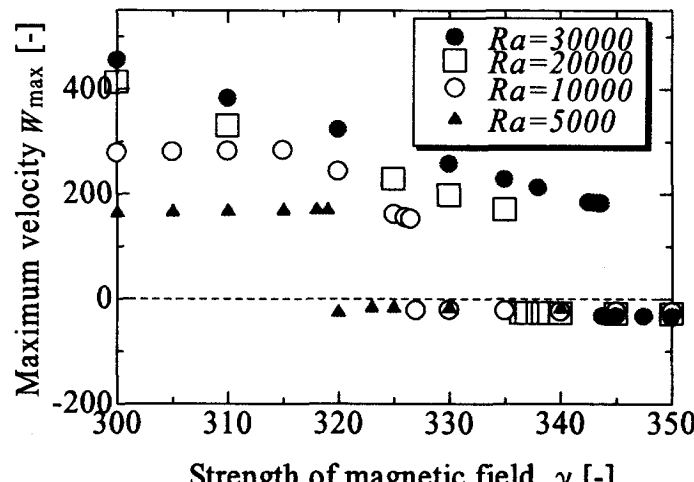

Fig.4 (b) Maximum axial velocity versus magnetic strength $(300<\gamma<350)$.

Table 1 Rayleigh number $R a$ and critical magnetic strength $\gamma_{\text {cr. }}$.

\begin{tabular}{|c|c|}
\hline Rayleigh number $R a$ & Critical magnetic strength $\gamma_{\mathrm{cr}}$ \\
\hline 5000 & $318<\gamma_{\mathrm{cr}}<320$ \\
\hline $10^{4}$ & $326.5<\gamma_{\mathrm{cr}}<327$ \\
\hline $2 \times 10^{4}$ & $335<\gamma_{\mathrm{cr}}<336.5$ \\
\hline $3 \times 10^{4}$ & $343.6<\gamma_{\mathrm{cr}}<343.75$ \\
\hline
\end{tabular}

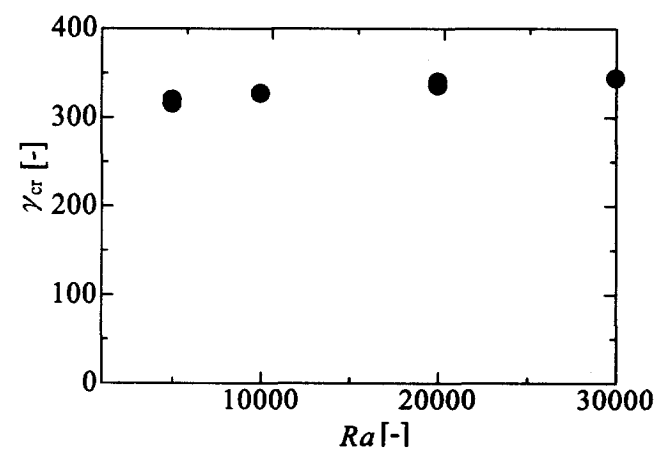

Fig.5 Critical magnetic strength $\gamma_{\mathrm{cr}}$ versus Rayleigh number $R a$.

\section{参考文献}

(1) Uetake H., et al., J. Appl. Phys., 85 (1999), 5735.

(2) Uetake, H., et al., J. Appl. Phys., 87(2000), 6310.

(3) Akamatsu, M., et al., Ann. NY Acad. Sci., 1077(2006), 613.

（4）安井, 赤松, 日向野, 日本機械学会東北支部第 42 回総 会・講演会論文集 No.2007-1(2007), 41-42. 